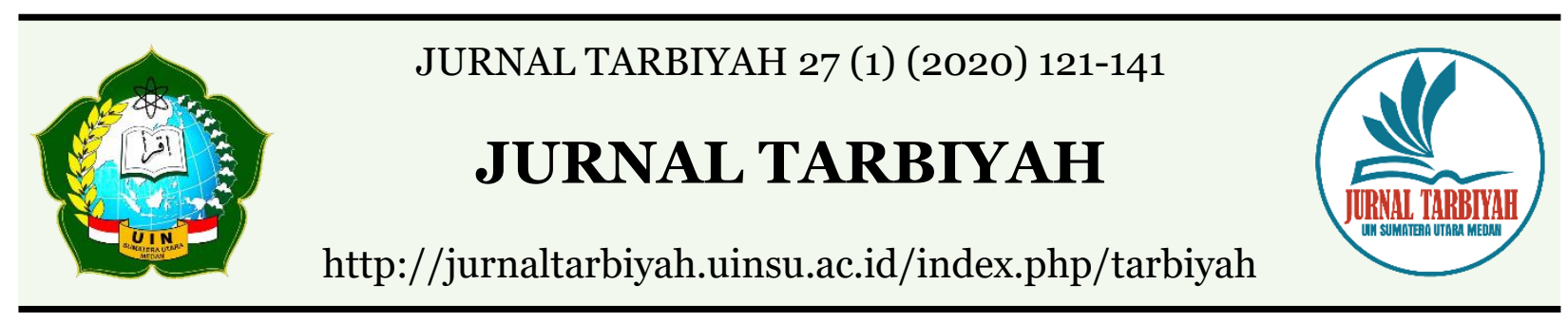

\title{
APPLICATION OF GUIDED QUESTION AND ANSWER METHOD TO IMPROVE PAI LEARNING ACHIEVEMENT OF STATE JUNIOR HIGH SCHOOL 1 SEI RAMPAH
}

\author{
Hadi Widodo \\ STKIP Amal Bakti, Medan, Indonesia \\ Email : $\underline{\text { hadiwidodo53@gmail.com }}$ \\ DOI : 10.30829/ tar.v27i1.687
}

Accepted: April 19th, 2020. Approved: June 25th, 2020. Published: June 30th, 2020

\begin{abstract}
This research is aimed to reveal the results of learning activities through classroom action research that have been applied for three cycles which each cycle consisted of planning, action, observation, and reflection. This research applied Guided Question and Answer to increase PAI learning achievement at State Junior High School. Based on all the discussions and analyzes that have been carried out, it can be concluded that there is the improvement in every cycle for the PAI students' achievement by using guided question and answer. By applying this method, the critical thinking of the students is improved as well. Moreover, learning achievement with the quidded question and answer method has positive impact on improving student learning achievement which is marked by increased student learning completeness in each cycle. In cycle I, the percentage of students learning minimal completeness criteria is $35.56 \%$. In cycle II, minimal completeness criteria is $49.22 \%$. Last, in cycle III, minimal completeness criteria is $85.20 \%$. Thus, the application of the guided question and answer method of learning has a positive effect.
\end{abstract}

Keywords: Guided Questions and Answers, Improving, PAI Subject Learning Achievement 


\section{INTRODUCTION}

Education should be implemtened throughout human life. As fact, within education, better of generations better will be produced. Education must be implemented to create useful person for individuals, the nation's interest, and for the country. To make humans have the abilities or skills needed by themselves, society and nation, the education should be implemented with high quality to produce individuals that have religious spiritual strength, self-control, and good character. One effort that can be applied is through formal education in schools.

The government continues to improve education in Indonesia from year to year. This improvement includes funding, infrastructure and incentives for teachers or educators that is increasing from year to year. Incentives by the government are not only given to teachers and public servants in schools but also private teachers through the payment of certification. All of these efforts are made only to improve the quality of education in Indonesia so that they can be aligned with developed countries. The purpose of theeducation can only be achieved if the school as a formal institution becomes an agent of renewal.

As a formal educational institution, schools are not only functioned to develop children's intelligence but also develop their personalities. As instance, for Islamic religion teachers of SMP Negeri 1 Sei Rampah, giving Islamic questions related to story problems is not easy. Generally, students who have understood the topic of Islamic religion theoretically have difficulty when the form of questions or problems are presented in the form of stories. Whereas, in the 1994 Basic Education curriculum, the function of teaching Islam is to prepare students to become citizens of a democratic society in everyday life through practical, varied, and applicative exercises. (Syahraini Tambak: 2014).

On the other hand, there are several students still face difficulties in reading Islamic religious texts. Meanwhile, students will more easily digest the questions about the class Islamic religion if students can read texts properly and correctly, understand the purpose of the stories, and understand the images involved For the majority of Islamic religious education teachers, teaching Islamic religious material relating to the ability of students to understand the problem description is still challenging.

Although a number of students have been able to understand the topic of Islamic religion theoretically, many have difficulty when the form of questions or problems are presented in the form of the problem description. In this case, the teacher is required to 
be able to provide material that is easily accepted by students. Besides, the teacher should provide a concrete and clear example relating to the question materials in the form of description. If these efforts can be applied well, hopefully student learning outcomes in Islamic subjects will also be improved.

Based on the situation, this research is conducted to develop effective learning strategies in understanding Islamic religious material for junior high school students. To achieve this goal, this research is applied in the form of classroom action research. Based on the description above, the paper is entitled by the researchers in this study is "The Application of Question and Answer Methods as an Effort to Improve the Learning Outcomes of Islamic Religion Education (PAI) Students of SMP Negeri 1 Sei Rampah.

\section{Literature Review}

\section{The Nature of Learning and Learning}

Learning cannot be separated from humans, in case essentially human learning is implemented throughout the life or at least by continuously learn even though the human graduated from formal or informal school. In the current era of globalization, where the environmental situation continues to change along with the rapid development of science and technology towards more modern, learning plays an important requirement.

Learning is a complex student's action and behavior. As an action, then learning is experienced, carried out and lived by the students themselves, where students are determinants of whether or not the learning process occurs. The learning process brings the students achieving something in the environment in the form of natural conditions, objects, animals, growing plants, humans, or things that are used as learning material (Dimyati \& Mudjiono, 1997: 7).

In this century, many learning theories theorized by experts. The following will elaborated several learning theories. Considering learning according to the view of the behavioristic theory of learning change in behavior as a result of the interaction between stimulus and response, student is considered to have learned something if he or she can show changes in his behavior (Budiningsih, 2005: 20). The cognitive theory defines that learning as a change in perception and understanding that cannot always be seen as visible behavior so that it can be assumed that the learning process will be achieved well if the subject matter or new information adapts to the cognitive structure that a person already has (Budiningsih, 2005: 51). 
Based on some of the definitions above, it can be concluded that the characteristics of learning activities are:

1. Learning is an activity that results in changes in individual learners

2. The change does not have to be immediately apparent after the learning process but can be observed in the coming opportunity

3. The change is essentially getting new skills

4. The change occurred as result of deliberate effort

Moreover, learning according to Gagne (1977) is "a set of events created and designed to encourage, encourage and support student learning."

Learning, in essence, is a process of interaction between students and their environment so that changes in behavior occur towards better interactaion. In the interaction, there are many factors that influence learning process, both internal factors that come from individuals and external factors that come from the environment. In learning, the most important task of the teacher is to create the good environment to support changes in behavior. (Dahar, R. W. 1998; Ausubel, D.P: 1983).

In creating conditions for learning, teachers use variety of methods and strategies, one of which is cooperative learning with the question and answer method. By using this learning method, understanding the materials provided by the teacher and can be gained it in the future.

\section{Various questions}

Judging from the time of delivery, the question is divided into three:

a) The initial question of the lesson, which is the introductory question intended to link past knowledge with new knowledge, stimulate learning interest to accept new lessons and focus their attention on the lesson.

b) Inquiry during the process of learning =teaching. This question is intended to discuss parts of the lesson and elaborate some new facts.

c) Questions end of the lesson, the lessons cover in referring to repeat, connecting the topic of the part, and make conclusions subjects so that students can understand the lessons easily.

Judging from the target, the question is basically can be divided into two, they are: the question of memory and thinking questions).

a) Memory question is intended to find out to what extent the knowledge has been mastered by students. The question words used are: what, who, where, when, and how 
much. For example, mention, who were the companions of the Prophet SAW. When Isra and Mi'raj of the Prophet (PBUH) happened? Which one includes al Sabiqunal A wwalun?

b) Questions of thought are intended to find out to what extent students think in responding to a problem. The question words used are: why and how. For example: Why do we have to maintain cleanliness? How should children show kindness to parents?

\section{The Fairness of Guided Question and Answer Method.}

The question and answer method will naturally be used to:

1. Summing up the lessons that have been explained by the teacher in outlining a problem, then the teacher filed a few questions. The questions were answered by the participant students while basil answer participant students who really prepared with good knowledge so that is an overview of the subjects that will be owned, participant students.

2. Continuing the lesson that already learnt. By repeating the lessons that have been given in the form of a question, the teacher will be able to attract the attention of participants of students to learn new materials

3. Attracting the attention of students to use their knowledge and experience.

4. Leading observation or thought participant students. When the participant students face problem than thought participant students can be guided by asking questions or a participant student who does not pay attention to the conversation teacher can arrange, so that his attention back to the description of the teachers to surprise them by giving a few questions.

5. Interspersing talks to excite the attention of the participant students in learning so that the way. Thus, there is a cooperation between the participant learners with the teacher and can give rise to the spirit of the participant students.

6. Examining the ability of the participant students in understanding a passage that read or lecture that has been heard. 


\section{Improper question and answer method}

Implementation of the question-and-answer-method is also not fair to matters as follows:

1. Assess students' level of ability regarding their learning. The question-and-answer method only give a rough idea and can only be used to recall what students learned or relate it to the lesson.

2. The problem is very complex while the answer is limited by the teacher. If the questions raised by the teacher gaine many answers, then do not limit the answers, but allow answering as widely as possible or if necessary carry out the method of discussion.

3. The questions asked should not be limited to "yes" or "no" answers, but the answers should encourage students' thinking to think of the right answer.

4. Give a turn only to certain students. Questions should be asked to all students, not only to certain students. Likewise in answering it, the chance should be given to all students, not only the smart ones. Even quiet or shy students are more encouraged to answer so that they can get used to it.

\section{Learning Steps}

The steps that must be applied in the implementation of the question and answer method are:

1. The objectives of the lesson should be clearly defined in advance.

2. The teacher should investigate whether the question and answermethod is the only method that most appropriate.

3. The teacher should examine what this method is used for, whether:
a) used to connect old lessons with new lessons
b) encourage students to use knowledge for solving problems
c) conclude a description
d) remind again of what is memorized students
e) guide their thinking
f) focus on students' attention.

4. Then the teacher must examine as well, whether:
a) the style of the question contains many problems or not
b) limited answers or not
c) only answered yes or no or is there to encourage students to think about answering it.

5. The teacher chooses which of the many answers can be accepted. 
6. The teacher should teach ways to prove the answers, by:
a) bring up fact quoted from books, magazines, dailies and so on
b) examine each answer by using the source
c) xplaine the chalkboard with various arguments station
d) compare with what students have ever seen
e) test the truth against skilled people
f) conduct experiments to prove the truth.

\section{Advantages of the guided question and answer method}

Some of the advantages of the-question-and-answer method are as follows:

1. Allow students to receive further explanation.

2. Teachers can immediately find out the progress of their students from the material explained

3. Difficult and rather good questions from students can encourage teachers to understand comprehensively and search for further sources.

\section{Weaknesses of the guided-question-and-answer method}

Some weaknesses in the question-and-answer-method:

1. More time is spent compared to the lecture method. The path of the lesson is slower than the lecture method so that sometimes it causes the learning material cannot be applied according to the set.

2. There may be differences of opinion between teachers and students. This happens because the experience of students are different with the teacher. If that happens the teacher and students should be able to prove the truth of the answer.

3. There is usually deviation from the main problem. Because the questions are always difficult then sometimes learners answers deviate from up the issue. If the problem happens, the teacher should take care of it so that new problems don't arise by making an effort. Hence. Teacher's attention is fixed on the original problem. If necessary, the teacher can change the structure of the questions or elaborate on the subject matter in several details.

4. If there are too many students, the time is limited to give each students their turn. 


\section{Research Methodology}

This research is action research due to the fact that it was conducted to solve learning problems in class. This research is also a descriptive study in case it illustrates how learning technique is applied and how the desired results can be achieved.

Suhardjono (2007: 5); (David Hopkins:2011) grouped action research into four types. They are: (a) the teacher acts as a researcher, (b) collaborative action research, (c) simultaneously integrated, and (d) experimental social administration.

In this action research, the teacher roles as the researchers who act as the person in charge of action research or as the practitioner (teacher). The main purpose of this action research is to improve learning outcomes in the classroom where the teacher is fully involved in research ranging from planning, action, observation, and reflection.

This study would be stopped when the mastery of learning catalytically reach $85 \%$ or more. So in this study, researchers do not depend on the number of cycles that should be passed. Location of research is a place used in research to obtain the desired data. This research was implemented at SMP Negeri 1 Sei Rampah, District of Sei Rampah, Serdang Bedagai Regency. Research time is the time the research takes place or when the research is carried out. This research was conducted in August 2019 until December 2019.

The research subjects were Grade VII.2 students of SMP Negeri 1 Sei Rampah for the 2019/2020 Academic Year, with total 36 students consisting of 20 women and 16 men. This research used Classroom Action Research (CAR). According to the PGSM Project Coaching Team, CAR is a form of a reflective study by action actors undertaken to improve the rational stability of their actions in carrying out the tasks, deeper understanding of the actions applied, and improve the conditions under which learning practices being implemented. (Siti Aisyah: 2014).

Moreover, according to Mukhlis (2000: 5 ), CAR is a form of a systematic reflective study by the executor of actions to improve the conditions of learning undertaken. The main purpose of CAR is to improve or enhance the practice of learning on an ongoing basis, while inclusion aims to foster a culture of research among teachers (Mukhlis, 2000: 5).

Following the type of research chosen, action research, this research applies the action research model from Kemmis and Taggart (in Sugiarti, 1997: 6), which is spiralshaped from one cycle to the next. Each cycle includes planning (plan), action (action), observation (observation), and reflection (reflection). The next step in the cycle are revised planning, action, observation, and 
reflection. Before conducting cycle 1, preliminary action was implemented in the form of problem identification. The spiral cycle of the stages of classroom action research can be seen in the following figure (Kemmis and Mc Taggart: 1998).

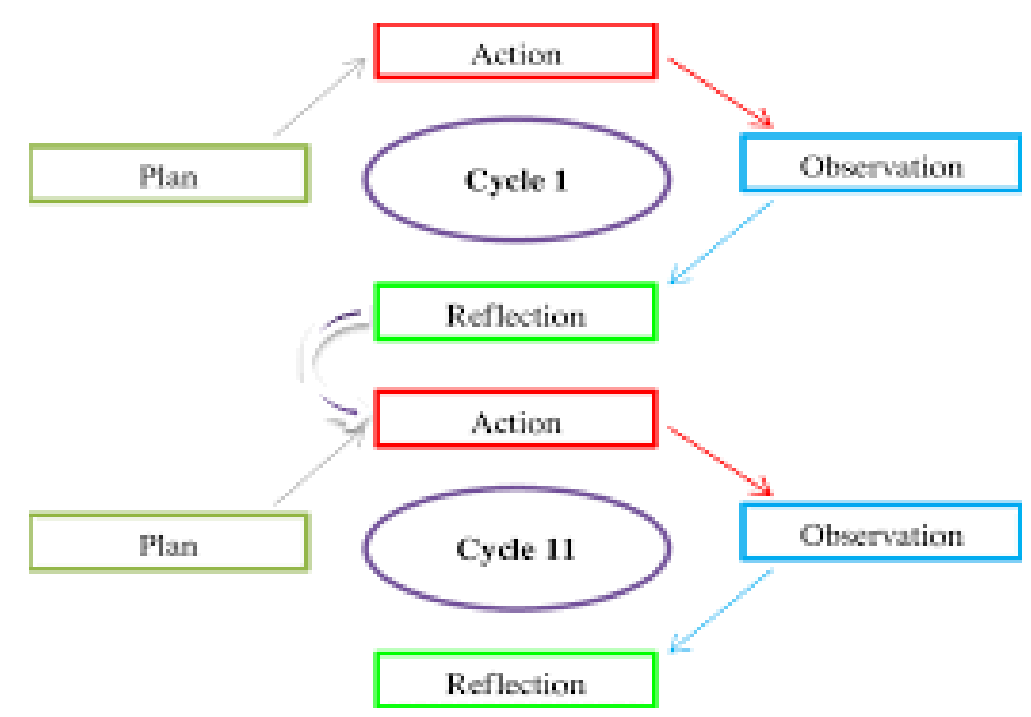

Figure 1. Classroom Action Research Cycle

The description of the figure above is as follow:

1. The initial design/plan. Before conducting research, the researcher formulates the problem formulation, objectives and makes an action plan, including research instruments and learning tools.

2. Activities and observations, including actions taken by researchers to build an understanding of student concepts and observe the results or impacts of the application of discovery model learning methods.

3. Reflection. The researcher examines, observes, and considers the results or impact of actions taken based on the observation sheet filled by the observer.

4. The revised plan, based on the reflection from the observer, creates the revised design to be implemented in the next cycle.

The observation was divided into three rounds, they are: round 1,2 , and 3 , where each round was subjected to the same treatment (same flow of activities) and discussed one sub-topic which ended with a formative test at the end of each round. The research was created in three rounds intended to improve the teaching system that has been implemented. The data needed in this study was obtained through observation of the 
question and answer method learning processing, observation of student and teacher activities, and formative tests.

To find out the effectiveness of method in learning activities, data analysis is needed. In this research, descriptive qualitative analysis techniques was used, which called as research method that describes the reality of facts following the data obtained to determine student achievement achieved, and also to obtain student responses to learning activities and student activities during the learning process.

To analyze the level of success or the percentage of students' success after the teaching and learning process, each round was finished by providing evaluation in the form of written test questions at the end of each round.

Moreover, there are two categories of mastery learning, individually and classically. Based on the implementation instructions for teaching and learning in the 1994 curriculum (Ministry of Education and Culture, 1994), student has finished learning when he or she has achieved score of $70 \%$ or 70 , and the class is determined being complete learning when there are $85 \%$ students in the class.

\section{Research Result}

The research data obtained are in the form of the test items, observation data in the form of question learning management observations, answer method and observations of student and teacher activities at the end of learning, and student formative test data in each cycle.

The test item test results were used to get tests that represent what the data possess. The data then was used to analyze the level of validity, reliability, level of difficulty, and distinguishing features.

Moreover, observation sheet data was taken from two observations: observational data of learning question and answer method which was used to determine the effect of the application of question, and answer method in improving achievement.

Meanwhile, formative test data was used to find out the increase in student learning achievement after the question and answer learning method is applied. 


\section{Cycle I}

a. Planning Stage

At this stage, the researcher prepared learning kit consisting of lesson plan 1, Students Answer Sheet 1 (LKS), formative test questions 1, and supporting teaching tools.

b. Activity and Implementation Stage

The implementation of teaching and learning activities for the first cycle was held in the class like the experimental class. In this case, the researcher acted as teacher. The teaching and learning process referred to the lesson plans that have been prepared. Observation (observation) was carried out simultaneously with the implementation of teaching and learning.

At the end of the teaching and learning process students were given a formative test I to find out the level of student success in the teaching and learning process previously. The research data in the first cycle were as follows:

Table 1. Recapitulation of Cycle I Test Results

\begin{tabular}{|c|l|c|}
\hline No & \multicolumn{1}{|c|}{ Description } & Cycle I Results \\
\hline 1 & The average value of formative tests & 50.27 \\
2 & Number of students who have completed Students' & 11 \\
3 & studies percentage of mastery learning & 30.56 \\
\hline
\end{tabular}

From the table above it can be explained that by applying the question and answer method of learning the average value of student achievement is 50.27 and completeness of learning reached $30.56 \%$ or there were 11 students out of 36 students who have finished learning process. These results indicated that in the first cycle classically students have not yet finished learning process because students who score $\geq 70$ were only $30.56 \%$ smaller than target completeness percentage in 85\%. This matter indicated that students still feel awkwardly suprised and did not understand what meant and used by the teacher by applying the question and answer method. 
Table 2. Observation Results of Cycle I Teachers

\begin{tabular}{|c|c|c|c|c|c|}
\hline \multirow{2}{*}{ Aspect } & \multirow{2}{*}{ Indicator } & \multicolumn{4}{|c|}{ Description } \\
\hline & & $\mathbf{1}$ & 2 & 3 & 4 \\
\hline $\begin{array}{l}\text { a. Lesson } \\
\text { Opening }\end{array}$ & $\begin{array}{l}\text { 1. Attracting the attention of students } \\
\text { 2. Explaining the purpose of learning } \\
\text { 3. Dividing and arrange students' groups }\end{array}$ & & & & \\
\hline $\begin{array}{l}\text { b. Use of time and } \\
\text { learning } \\
\text { strategies }\end{array}$ & $\begin{array}{l}\text { 1. Providing source of learning and tools to } \\
\text { help subjects was obtained } \\
\text { 2. Implementing student learning activities with o } \\
\text { ne earning objectives }\end{array}$ & & & & \\
\hline $\begin{array}{l}\text { c. Involvement in } \\
\text { the learning } \\
\text { process }\end{array}$ & $\begin{array}{l}\text { 1. Teacher efforts involve students in the learning } \\
\text { process } \\
\text { 2. Observing student activities in completing } \\
\text { group discussions. }\end{array}$ & & & & \\
\hline $\begin{array}{l}\text { d. Communicatio } \\
\text { n with } \\
\text { students }\end{array}$ & $\begin{array}{l}\text { 1. Disclosure of questions was clear and precise } \\
\text { 2. Responsing to questions of students } \\
\text { 3. Developing students' courage in giving opinions. }\end{array}$ & & & & \\
\hline e. Close & 1. Summing up the contents of the lesson & & & & \\
\hline & Number of Descriptors & 4 & 2 & 3 & 2 \\
\hline & Score & 4 & 4 & 9 & 8 \\
\hline
\end{tabular}

From the table above, it can be seen the results of observations as follows: $\mathrm{P}=$ and the rating category is not good. Thus, researchers have achieved only 59.09\% of all indicators that must be implemented.

Table 3. Observation Results of Student Cycle I Activities

\begin{tabular}{l|l|l} 
Aspect & Indicator & Score
\end{tabular}




\begin{tabular}{|c|c|c|c|c|c|}
\hline & & $\mathbf{1}$ & 2 & 3 & 4 \\
\hline $\begin{array}{l}\text { 1. Diligently } \\
\text { faced duty }\end{array}$ & $\begin{array}{l}\text { a. Conducting continuous learning activities. } \\
\text { b. Giving attention and concentration. } \\
\text { c. Intentions given are high to do the task. } \\
\text { d. Understanding the material that was described } \\
\text { by both. }\end{array}$ & & & & \\
\hline $\begin{array}{l}\text { 2. } \quad \text { Resilient } \\
\text { faced } \\
\text { difficulties }\end{array}$ & $\begin{array}{l}\text { a. Not quick satisfaction by the } \\
\text { achievements were reached } \\
\text { b. Getting good value } \\
\text { c. Trying to complete tasks } \\
\text { d. Working alone in doing tasks }\end{array}$ & & & & \\
\hline $\begin{array}{l}\text { 3. Happy to find } \\
\text { and solve the } \\
\text { problems }\end{array}$ & $\begin{array}{l}\text { a. Having active nature inquiry in learning } \\
\text { b. Actively asking and answering questions } \\
\text { c. Student collaboration in groups }\end{array}$ & & & & \\
\hline \multicolumn{2}{|c|}{ Number of Descriptors } & & 5 & 5 & \\
\hline \multicolumn{2}{|l|}{ Score } & & 10 & 10 & 4 \\
\hline
\end{tabular}

In accordance with the table above, the percentage of observations of student activities during teaching and learning activities was good and so the assessment category. Thus it can be concluded that during the teaching and learning process, $54.54 \%$ of student activity had been going well as expected. However, some improvements need to be made to the aspect that still minimum.

\section{Cycle II}

a. The planning stage

At this stage, the researcher prepared learning kit consisting of lesson plan 2, LKS 2, formative test questions II, and supporting teaching tools.

b. Activity and implementation stage

The implementation of teaching and learning activities for the second cycle was held after reflection on cycle I. In this case, the researchers acted as the teacher. The teaching and learning process referred to the lesson plan by giving attention to 
revisions in the first cycle, so that mistakes or deficiencies in the first cycle would not be repeated in the second cycle. Observation was carried out simultaneously with the implementation of teaching and learning.

At the end of the teaching and learning process, students were given a formative test II to know the level of student success during the teaching and learning process that has been carried out. The instrument used was formative test II. The research data in the second cycle are as follows.

Table 4. Recapitulation of Cycle II Test Results

\begin{tabular}{|c|l|c|}
\hline No & \multicolumn{1}{|c|}{ Description } & Cycle II Results \\
\hline 1 & The average value of formative tests & 59.17 \\
2 & Number of students who have completed their studies & 17 \\
3 & Percentage of mastery learning & 47.22 \\
\hline
\end{tabular}

From the table above, the average value of student achievement is 59.17, and mastery learning reaches $47.22 \%$ or there were 17 students out of 36 students who have finished learning. These results indicate that in this second cycle classical learning completeness has experienced a slightly better improvement than cycle I. There was an increase in student learning outcomes because after the teacher informed that at the end of each lesson there will always be a test so that at the next meeting students felt more motivated to learn. Besides, students also have begun to understand what the teacher intended and planned by applying the question and answer method.

Table 5. Observation Results of Cycle I Teachers

\begin{tabular}{|c|c|c|c|c|c|}
\hline \multirow[t]{2}{*}{ Aspect } & \multirow[t]{2}{*}{ Indicator } & \multicolumn{4}{|c|}{ Description } \\
\hline & & $\mathbf{1}$ & 2 & 3 & 4 \\
\hline $\begin{array}{l}\text { a. Lessons } \\
\text { Opening }\end{array}$ & $\begin{array}{l}\text { 1. Attracting the attention of students } \\
\text { 2. Explaining the purpose of learning } \\
\text { 3. Dividing and arranging students' groups }\end{array}$ & & & & \\
\hline $\begin{array}{l}\text { b. Use of time and } \\
\text { learning strategies }\end{array}$ & $\begin{array}{l}\text { 1. Providing source of learning and tools to } \\
\text { help subjects was obtained } \\
\text { 2. Carrying out student learning activities } \\
\text { with learning objectives }\end{array}$ & & & & \\
\hline
\end{tabular}




\begin{tabular}{|c|c|c|c|c|}
\hline $\begin{array}{l}\text { c. Involvement in } \\
\text { the learning } \\
\text { process }\end{array}$ & $\begin{array}{l}\text { 1. Teacher efforts involve students in the } \\
\text { learning process } \\
\text { 2. Observing students' activities in } \\
\text { completing group discussions. }\end{array}$ & & & \\
\hline $\begin{array}{l}\text { d. Communication } \\
\text { with students }\end{array}$ & $\begin{array}{l}\text { 1. Disclosure of questions was clear } \\
\text { and precise } \\
\text { 2. Giving response to questions of students } \\
\text { 3. Developing students' courage in opinions }\end{array}$ & & & \\
\hline e. Close & 1. Summing up the contents of the lesson. & & & \\
\hline \multicolumn{2}{|r|}{ Number of Descriptors } & 4 & 5 & 2 \\
\hline \multicolumn{2}{|r|}{ Score } & 8 & 15 & 8 \\
\hline
\end{tabular}

From the above table, it can be seen the results of observations as follows: $\mathrm{P}=$ and the assessment category was good. Thus researchers have achieved $70.45 \%$ of all indicators that should be implemented properly.

Table 6. Observation Results of Student Cycle I Activities

\begin{tabular}{|c|c|c|c|c|c|}
\hline \multirow[t]{2}{*}{ Aspect } & \multirow[t]{2}{*}{ Indicator } & \multicolumn{4}{|c|}{ Score } \\
\hline & & 1 & 2 & 3 & 4 \\
\hline $\begin{array}{l}\text { 1. Diligently faced } \\
\text { Duty }\end{array}$ & $\begin{array}{l}\text { 1. Doing activities to } \\
\text { learn CONSEQUENTIAL constantly } \\
\text { 2. Giving attention and concentration } \\
\text { 3. Intentions given are high to do the task } \\
\text { 4. Understanding the material that is } \\
\text { described by both. }\end{array}$ & & & & \\
\hline $\begin{array}{l}\text { 2. Resilient faced } \\
\text { Difficulties }\end{array}$ & $\begin{array}{l}\text { 1. No quick satisfaction with the } \\
\text { achievements are reached } \\
\text { 2. Getting good value } \\
\text { 3. Trying to complete tasks } \\
\text { 4. Working alone in doing tasks }\end{array}$ & & & & \\
\hline
\end{tabular}




\begin{tabular}{|l|l|l|l|l|}
\hline $\begin{array}{l}\text { 3. Happy to find } \\
\text { and solve } \\
\text { problems }\end{array}$ & $\begin{array}{l}\text { 1. Having an active nature in learning. } \\
\text { 2. Actively asking and answering questions. }\end{array}$ & & & \\
& & & & \\
& & & \\
\hline Number of Descriptors & & 1 & 7 & 3 \\
\hline Score & & 2 & 21 & 12 \\
\hline
\end{tabular}

In accordance with the observation data on table above, the percentage of observations of student activities during teaching and learning activities was good and so the assessment category. Thus, it can be concluded that during the teaching and learning process, $79.55 \%$ of student activity had been going well as expected. However, some improvements need to be made to the parts that are considered still lacking.

\section{Cycle III}

a. Planning Stage

At this stage, the researchers prepared learning kit consisting of lesson plan 3 , worksheet 3 , formative test questions 3 , and teaching tools.

b. Activity and observation stage

The implementation of teaching and learning activities for cycle III was carried out after reflecting on cycle II. In this case, the researcher acted as the teacher. The teaching and learning process referred to the lesson plan by giving attention to the revisions in the second cycle, so mistakes or deficiencies in the second cycle would not be repeated in the third cycle. Observation was carried out simultaneously with the implementation of teaching and learning.

At the end of the teaching and learning process, students were given a formative test III to determine the level of student success in the teaching and learning process that has been implemented. The instrument used was formative test III. The research data in cycle III were as follows:

Table 7. Recapitulation of Cycle III Test Results

\begin{tabular}{|c|l|c|}
\hline No & \multicolumn{1}{|c|}{ Description } & Cycle III results \\
\hline 1 & The average value of formative tests & 76.67 \\
\hline
\end{tabular}




\begin{tabular}{|c|l|c|}
\hline 2 & $\begin{array}{l}\text { Number of students who have completed their } \\
\text { studies }\end{array}$ & 32 \\
3 & Percentage of mastery learning & 88.19 \\
\hline
\end{tabular}

Based on the table above, it was obtained an average value of formative tests of 76.67, where among 36 students, 32 students have completed 32 students and 4 students have not reached mastery learning. So classically mastery learning that has been reached was $88.19 \%$ (including the category of completion). Results in cycle III have been improving better than cycle II. An increase in learning outcomes in the third cycle was influenced by an increase in the ability of teachers to apply the learning method of question and answer so that students become more accustomed to learn. Thus, the students more easily understand the material that has been given. In this cycle III, the classical completeness has been achieved, so this study only reached the third cycle.

Table 8 . Observation Results of Cycle Teachers III

\begin{tabular}{|c|c|c|c|c|}
\hline \multirow[t]{2}{*}{ Aspect } & \multirow[t]{2}{*}{ Indicator } & \multicolumn{3}{|c|}{\begin{tabular}{|l} 
Description \\
\end{tabular}} \\
\hline & & \begin{tabular}{|l|l|}
$\mathbf{1}$ & $\mathbf{2}$ \\
\end{tabular} & 3 & 4 \\
\hline $\begin{array}{l}\text { a. Lesson } \\
\text { Opening }\end{array}$ & $\begin{array}{l}\text { 1. Attracting the attention of students } \\
\text { 2. Explaining the purpose of learning } \\
\text { 3. Dividing and arrange students' groups }\end{array}$ & & & \\
\hline $\begin{array}{l}\text { b. Use of time } \\
\text { and learning } \\
\text { strategies }\end{array}$ & $\begin{array}{l}\text { 1. Providing source of learning and tools to } \\
\text { help subjects was obtained } \\
\text { 2. Implementing student learning activities with } \\
\text { one earning objectives }\end{array}$ & & & \\
\hline $\begin{array}{l}\text { c. Involvement in } \\
\text { the learning } \\
\text { process }\end{array}$ & $\begin{array}{l}\text { 1. Teacher efforts involve students in the } \\
\text { learning process } \\
\text { 2. Observing student activities in completing } \\
\text { 3. Group discussions. }\end{array}$ & & & \\
\hline $\begin{array}{l}\text { d. Communicatio } \\
\text { n with students }\end{array}$ & $\begin{array}{l}\text { 1. Disclosure of questions was clear and precise } \\
\text { 2. Responsing to questions of student } \\
\text { 3. Developing students' courage in } \\
\text { giving opinions. }\end{array}$ & & & \\
\hline
\end{tabular}




\begin{tabular}{|c|c|c|c|}
\hline e. Close & 1. Summing up the contents of the lesson & & \\
\hline & Number of Descriptors & 4 & 7 \\
\hline & Score & $\begin{array}{l}1 \\
2\end{array}$ & $\begin{array}{l}2 \\
8\end{array}$ \\
\hline
\end{tabular}

From the table above, it can be seen the percentage of observations as follows: = 90.90\% the assessment category was very good. Thus researchers have done 90, 90\% of all indicators.

Table 9. Observation Results of Student Activity Cycle III

\begin{tabular}{|c|c|c|c|c|c|}
\hline \multirow[t]{2}{*}{ Aspect } & \multirow[t]{2}{*}{ Indicator } & \multicolumn{4}{|c|}{ Score } \\
\hline & & $\mathbf{1}$ & 2 & 3 & 4 \\
\hline $\begin{array}{l}\text { 1. Diligently faced } \\
\text { Duty }\end{array}$ & $\begin{array}{l}\text { a. Doing activities to } \\
\text { learn CONSEQUENTIAL constantly } \\
\text { b. Giving attention and concentration } \\
\text { c. Intentions given are high to do the task } \\
\text { d. Understanding the material that is } \\
\text { described by both. }\end{array}$ & & & & \\
\hline $\begin{array}{l}\text { 2. Resilient faced } \\
\text { Difficulties }\end{array}$ & $\begin{array}{l}\text { a. No quick satisfaction with the } \\
\text { achievements are reached } \\
\text { b. Getting good value } \\
\text { c. Trying to complete tasks } \\
\text { d. Working alone in doing tasks }\end{array}$ & & & & \\
\hline $\begin{array}{l}\text { 3. Happy to find } \\
\text { and solve } \\
\text { problems }\end{array}$ & $\begin{array}{l}\text { a. Having an active nature in learning. } \\
\text { b. Actively asking and answering questions. } \\
\text { c. Student collaboration in groups }\end{array}$ & & & & \\
\hline & Number of Descriptors & & & 4 & 7 \\
\hline & Score & & & 12 & 28 \\
\hline
\end{tabular}

By the observation data on table above, the percentage of observations of student activities during teaching and learning activities was good and so the is the category of assessment. Thus, it can be concluded that during the teaching and learning process, 90.90\% of student activity has been going well as expected. 


\section{c. Reflection}

At this stage, the researchers examined what has been done well and what being in low score in the teaching and learning process by applying the learning question and answer method. From the data that has been obtained can be described as follows:

1) During the teaching and learning process, the teacher has carried out all learning ways well. Although some aspects were not perfect, the percentage of implementation for each aspect was quite large.

2) Based on observational data, it is known that students were active during the learning process.

3) Deficiencies in the previous cycles have brought improvements so that it created better result.

4) Student learning outcomes in cycle III have achieved the completeness.

\section{Implementation Revision}

In cycle III, the teacher has applied the question and answer learning method well. By seeing from student activities and student learning outcomes, the implementation of teaching and learning process has been going well. So revisions is not necessary so far, but what needs to be considered for further action is to maximize and maintain what has been exist, with the aim that in the implementation of the teaching and learning process further, the application of question and answer methods can improve the teaching and learning process so that learning objectives can be achieved.

Through the results of this study, it indicates that the learning question and answer method brings positive impact on improving student learning achievement. It can be seen from the increasing consolidation of student understanding of the material that were presented by the teachers (mastery learning increased from skills I, II, and II I) was in $30.56 \%, 47.22 \%$, and $88.19 \%$. In cycle III, students' classical learning completeness has been achieved.

2. Teacher's Ability in Managing Learning

Based on data analysis, it was obtained student activity in the process of learning question and answer methods in each cycle has increased. This brings positive impact on student achievement, which can be seen on the increase of average value of students in each cycle.

3. Teacher and Student Activities in Learning 
Based on data analysis, it was obtained student activities in the learning process of Islam on the most dominant composing subjects are working by using tools/media, by giving attention to teacher explanations, and discussions between students or between students and teachers. So it can be concludet that student activities can be categorized into active category.

Thus, the activities of the teacher during learning has carried out the steps of learning the question and answer method properly. It can be seen from the teacher's activities that arise including the activity of guiding and observing students in working on their LKS activities / finding concepts, explaining / training using tools, giving feedback / evaluating / asking questions where the percentage for the above activities are quite large.

\section{CONCLUSION}

From the results of the learning activities that have been carried out for three cycles, and based on all the discussions and analysis, it can be concluded that:

1. Learning with the question and answer method has positive impact on improving student achievement which is marked by an increase in student learning completeness in each cycle: cycle I (35.56\%), cycle II (49.22\%), and cycle III $(85,20 \%)$.

2. The application of the question and answer method of learning brings positive effect, which can increase student motivation as shown by the results of interviews with some students, where in average students stated that they are interested in the question and answer learning methods so that they become motivated to learn.

\section{REFERENCES}

Ausubel, D.P. 1983. The Psikologi of Meaningful Verbal Learning, New York: Grune \& St;rton.

Budiningsih, Asri. 2005. Belajar dan Pembelajaran. Jakarta: Rineka Cipta.

Dahar, R. W. 1988. Teori-teori Be/ajar. Jakarta : Penerbit Erlangga.

David Hopkins. 2011. Panduan Guru Penelitian Tindakan Kelas. Yogyakarta: Pustaka Pelajar.

Dimyati \& Mudjiono, 1997. Belajar dan Pembelajaran. Jakarta: Rineka Cipta.

Gagne. R.M, 1977. The Condition of Learning. New York: Holt, Renehart and Wiston. Kemmis and MC Taggart.1998. The Action Research Planner. Dekan University. 
Mukhlis Abdul. (Ed). 2005. Penelitian Tindakan Kelas. Jakarta. Bumi Aksara.

Siti Annisah, 2014. Penerapan Metode Mind Map Dalam Meningkatkan Kemampuan Berfikir Kreatif Mahasiswa (Penelitian Tindakan Kelas Pada Mahasiswa Pgmi Semester V Stain Jurai Siwo Metro). Jurnal Tarbiyah. Vol. 21, No 1.

Suhardjono. 2007. Penelitian tindakan kelas. Jakarta: Bumi Aksara.

Syahraini Tambak. 2014. Metode Ceramah: Konsep Dan Aplikasi Dalam Pembelajaran Pendidikan Agama Islam. Jurnal Tarbiyah. Vol. 21, No 2. 